\title{
FIRST-LINE TREATMENT OF ADVANCED OVARIAN CANCER: AN EXPERT UPDATE
}

\author{
BRANKA PETRIĆ MIŠE \\ Department of Oncology, University Hospital Split and School of Medicine Split, Croatia
}

\begin{abstract}
Summary
Ovarian cancer is the fifth most common cause of death among malignant diseases in women in Europe. The standard treatment is cytoreductive surgery, followed by platinum-taxane based chemotherapy. In patients with advanced disease, a valid option is a neoadjuvant chemotherapy followed by interval debulking surgery. Despite the progress in primary treatment, almost $70 \%$ of the patients relapse. There is a significant need for better first-line treatment to avoid or delay relapse and improve ovarian cancer outcomes. The most significant change involves the changes in the treatment schedule and new drugs in first-line chemotherapy. Bevacizumab is approved in first-line treatment combined with carboplatin and paclitaxel as it improves progression-free survival (PFS) in patients with a higher risk of recurrence. After achieving the response to first-line chemotherapy, maintenance therapy with poly-adenosine-diphosphate-ribose-polymerase (PARP) inhibitors prolongs PFS in patients with homologous recombination deficiency (HRD). Patients with BRCA mutations obtain the most significant benefit.
\end{abstract}

KEYWORDS: ovarian cancer, chemotherapy, Bevacizumab, PARP inhibitors

Ovarian cancer is the most lethal gynecologic cancer. Primary debulking surgery, followed by a combination of platinum-paclitaxel-based chemotherapy, is currently considered as the standard of care for advanced epithelial ovarian cancer (1). The introductions of weekly paclitaxel therapy and intraperitoneal chemotherapy are standard treatment options for patients with ovarian cancer, except for the disease's early stage (1). The introductions of weekly paclitaxel and intraperitoneal chemotherapy are recognized alternatives considered acceptable as primary treatment $(2,3)$. In patients with considerable and aggressive tumor dissemination or in patients with advanced disease where $\mathrm{R} 0$ resection cannot be achieved, an alternative treatment strategy is neoadjuvant chemotherapy with delayed surgery (i.e., interval de-

Corresponding author: Branka Petrić Miše, Department of Oncology, University Hospital Split and School of Medicine Split, Soltanska 2, 21000 Split, Croatia.

e-mail:brapemi@gmail.com bulking surgery). After neoadjuvant chemotherapy, delayed cytoreductive surgery is not inferior to primary debulking surgery, as shown in randomized, controlled trials $(4,5)$.

Despite the progress achieved in the last decades, almost $70 \%$ of the patients experience a relapse. The most significant breakthrough in the last decades was the addition of new drugs (6).

The targeted therapy is presumably less toxic than polychemotherapy and neo-angiogenesisis widespread in solid-tumor growth and metastasis. Therefore research has been concentrated on antiangiogenetic drugs. The rationale to use an antiangiogenic treatment in cancer is the presence of hypoxia in cancer tissue. The reduction of oxygen promotes vascular endothelial growth factor (VEGF) receptors on the endothelial cells. Subsequently, the binding of circulating vascular endothelial growth factor with the receptor leads to new vessels' proliferation, promoting tumor growth (7). 
Bevacizumab, a humanized monoclonal IgG antibody that targets vascular endothelial growth factor receptor, has been one of the first and most investigated antiangiogenetic drugs. It also demonstrated efficacy in ovarian cancer. This inhibition leads to a reduction of neo-angiogenesis and an increase in vascular permeability. Consequently, a higher dose of chemotherapeutic agents is released, finally resulting in tumor endothelial cells apoptosis(7).

Bevacizumab is approved 2011 by the European Medicines Agency (EMA) and 2018 by the Food and Drug Administration (FDA) for the firstline treatment in patients with ovarian cancer, fallopian tube, and primary peritoneal cancers stage III and IV in combination with carboplatin and paclitaxel. The approval is based on the results of a multicenter, phase III trial. The Gynecologic Oncology Group trial (GOG-0218) involved 1873 women with stage III/IV ovarian cancer. After primary debulking surgery, patients were randomized to receive the standard treatment (carboplatin and paclitaxel - group A) or add Bevacizumab from cycles 2 through 6 , followed by placebo B, or Bevacizumab from cycles 2 through 22 - group C). Bevacizumab was administered at a dosage of 15 $\mathrm{mg} / \mathrm{kg}$ every three weeks. The study's primary endpoint was progression-free survival (PFS), with overall survival (OS) as a secondary end point. The median PFS was 10.3, 11.2, and 14.1 months in group $A$, group $B$, and group $C$, respectively (HR for group $B$ compared with the control group was $0.717 ; P=0.001)(8)$. The final data for OS presented at the 2018 American Society of Clinical Oncology (ASCO) did not demonstrate a difference among the groups in terms of OS (HR for group B vs. group $A$ was 1.06; $P=0.34$, and for group $C$ vs. group A was 0.96 ; $P=0.53$ ) (9).

The International Collaborative Ovarian Neoplasm Trial 7 (ICON-7) was another phase III randomized trial enrolling 1528 patients with FIGO stage I-IIA clear-cell/grade 3 or FIGO stage III/IV epithelial ovarian cancer, primary peritoneal or fallopian tube cancer, to receive six cycles of 3-weekly carboplatin and paclitaxel with or without Bevacizumab $(7.5 \mathrm{mg} / \mathrm{kg}$ ) for 12 months. The primary endpoint was PFS. The median PFS was 17.4 months for the control group vs. 19.8 months for the bevacizumab group $(P=0.004)(10)$. Similar to the GOG-0218 study, no differences in the OS rate were reported after 49 months of follow-up
(44.6 vs. 45.5 months for the control and bevacizumab groups, respectively, $P=0.85$ ) (11). In both the studies, ICON-7, and GOG-0218, high-risk patients seem to benefit the most from the addition of Bevacizumab. The "higher risk" was defined as a patient with a FIGO stage III tumor, suboptimally debulked (residual disease) or stage IV (8-11).

In both GOG-0218 and ICON-7 trials, Bevacizumab was given concurrently with the traditional 3-weekly carboplatin/ paclitaxel chemotherapy. However, the Japanese Gynecologic Oncology Group (JGOG), demonstrated a better prognosis in patients treated with a dose-dense strategy (carboplatin 3-weekly and paclitaxel weekly vs. carboplatin and paclitaxel 3-weekly). This opened the question of which schedule is better. Subsequently, the Multicenter Italian Trials in Ovarian Cancer (MITO) studied another schedule of treatment. In the MITO-7 trial, carboplatin (AUC 2) plus paclitaxel $\left(60 \mathrm{mg} / \mathrm{m}^{2}\right)$ administrated both weekly was compared with the standard treatment. Comparable results in terms of PFS with less adverse events were found in the weekly schedule (PFS was 18.8 vs 16.5 months, $P=0.18$ ) (12). The phase III trial ICON-8 was conducted to investigate the weekly chemotherapy in the European population. At the European Society for Medical Oncology (ESMO) Virtual Congress 2020, final analysis of ICON-8 confirmed that weekly dose-dense chemotherapy with paclitaxel or paclitaxel/carboplatin could be successfully and safely administered as first-line treatment for epithelial ovarian cancer but without OS or PFS benefits over standard 3-weekly chemotherapy (13).

According to the EMA and FDA approval, the current administration of Bevacizumab is up to 22 cycles (15 months). In the GOG-0218, Bevacizumab was administrated for 15 months, in the ICON-7 for 12 months. The ROSiA study, a singlearm phase 3B study was designed, to evaluate the efficacy and safety of prolonging Bevacizumab beyond 15 months. According to the acceptable toxicity profile, and the longest reported PFS for frontline bevacizumab-containing therapy, treatment prolongation with Bevacizumab seems to be feasible (14). The conclusion could be drawn only when the final results of AGO OVAR17, a phase III randomized controlled trial comparing 15 vs. 30 months of bevacizumab therapy, will be available in 2021 (15) (Table 1). 
Lib Oncol. 2020;48(2-3):77-84

Table 1.

Bevacizumab in first-line treatment

\begin{tabular}{|c|c|c|c|c|}
\hline Study & Patients & Study arm (S) & Control arm (C) & Results \\
\hline GOG-0218 & Stage III-IV & $\begin{array}{l}\text { S1: Carboplatin + paclitaxel q3w } \\
+ \text { bevacizumab } 15 \mathrm{mg} / \mathrm{kg} \mathrm{q} 3 \mathrm{w} \\
\text { from cycle } 2 \text { through } 6 \\
\text { S2: Carboplatin }+ \text { paclitaxel q3w } \\
+ \text { bevacizumab } 15 \mathrm{mg} / \mathrm{kg} \mathrm{q} 3 \mathrm{w} \\
\text { from cycle } 2 \text { through } 22 \text { for } 15 \text { months }\end{array}$ & $\begin{array}{l}\text { Carboplatin } \\
+ \text { paclitaxel q3w } \\
+ \text { placebo }\end{array}$ & $\begin{array}{l}\text { PFS } 11,2 \text { (S1) vs } 14,1(\mathrm{~S} 2) \\
\text { vs } 10,3 \text { months }(\mathrm{C}) \\
\text { HR } 0.717 \\
P=0.34 \\
\text { OS } 38,7(\mathrm{~A}) \text { vs } 39,7(\mathrm{~B}) \\
\text { vs } 39,3 \text { months }(\mathrm{C}) ; \\
\text { HR } 0.96 ; \\
P=0.53\end{array}$ \\
\hline ICON-7 70,11 & $\begin{array}{l}\text { Stage I-II G3 } \\
\text { or clear cell } \\
\text { or stage IIB-IV }\end{array}$ & $\begin{array}{l}\text { Carboplatin + paclitaxel q3w } \\
\text { + bevacizumab } 7,5 \mathrm{mg} / \mathrm{kg} \mathrm{q} 3 \mathrm{w} \\
\text { for } 12 \text { months }\end{array}$ & $\begin{array}{l}\text { Carboplatin } \\
+ \text { paclitaxel q3w }\end{array}$ & $\begin{array}{l}\text { PFS } 19,8(\mathrm{~S}) \text { vs } 17,4 \text { months }(\mathrm{C}) \text {; } \\
P=0.004 \\
\text { OS } 45,5(\mathrm{~S}) \text { vs } 44,6 \text { months }(\mathrm{C}) \\
P=0.85\end{array}$ \\
\hline $\mathrm{ROSiA}^{14}$ & $\begin{array}{l}\text { Stage IIB-IV } \\
\text { or grade } 3 \text { stage } \\
\text { I-IIA }\end{array}$ & $\begin{array}{l}\text { Carboplatin + paclitaxel q3w } \\
\text { + bevacizumab } 7,5 \text { or } 15 \mathrm{mk} / \mathrm{kg} \mathrm{q} 3 \mathrm{w} \\
\text { for } 24 \text { months }\end{array}$ & Not available & PFS 25,5 months (S) \\
\hline
\end{tabular}

Table 2.

Bevacizumab in neoadjuvant treatment

\begin{tabular}{|l|l|l|l|l|}
\hline Study & Patients & Study arm (S) & Control arm (C) & Results \\
\hline ANTHALYA & Stage IIIC-IV & $\begin{array}{l}\text { NACT: Carboplatin + paclitaxel q3w 1-4 cycle } \\
\text { + bevacizumab 15 mg/kg q3w 1-3 cycle } \\
\text { ADJ: Carboplatin + paclitaxel q3w 5-8 cycle } \\
\text { + bevacizumab 15 mg/kg q3w 6-26 cycle }\end{array}$ & $\begin{array}{l}\text { NACT: Carboplatin + paclitaxel } \\
\text { q3w 1-4 cycle } \\
\text { ADJ: Carboplatin + paclitaxel } \\
\text { q3w 5-8 cycle + bevacizumab } \\
15 \mathrm{mg} / \mathrm{kg} \text { q3w 6-26 cycle }\end{array}$ & $\begin{array}{l}\text { CRR 58,6\% (S) } \\
\text { vs 51,4\% (C) }\end{array}$ \\
\hline $\begin{array}{l}\text { MITO 16A-Mango } \\
\text { OV2A }^{17}\end{array}$ & Stage IIIB-IV & $\begin{array}{l}\text { NACT: Carboplatin + paclitaxel q3w } \\
\text { + bevacizumab 15 } \mathrm{mg} / \mathrm{kg} \text { q3w } \\
\text { ADJ: Carboplatin + paclitaxel q3w cxcle } \\
\text { + bevacizumab 15 mg/kg q3w up to } \\
\text { a max 16 additional cycles }\end{array}$ & Not available & \\
\hline
\end{tabular}

Bevacizumab is investigated in neoadjuvant treatment along with chemotherapy. ANTHALYA trial was a phase II multicenter randomized trial aimed to evaluate the safety and efficacy of Bevacizumab in a neoadjuvant setting. Patients initially received four cycles of neoadjuvant 3-weekly carboplatin-paclitaxel chemotherapy with or without three cycles of Bevacizumab followed by interval debulking surgery. After surgery, adjuvant chemotherapy was administrated, reintroducing Bevacizumab at cycle six and maintained for at least 26 cycles. The complete resection rate (CRR) was higher in the group with Bevacizumab (85.5\%) with an acceptable toxicity profile (16). These data were confirmed in a more recent phase IV study, the MITO16A-Mango OV2A, a trial designed to find a prognostic factor to individualize the therapy with Bevacizumab (17). Although Bevacizum$\mathrm{ab}$ has been investigated in a few neoadjuvant studies, further studies are necessary to draw definitive conclusions (Table 2).
Angiogenesis plays a vital role in ovarian cancer, but it is still not clear in which category of patients the addition of antiangiogenic therapy could improve the prognosis. In the ICON-7 study, molecular analysis was done. Four molecular subtypes were found: differentiated $(20 \%)$, immunoreactive $(34 \%)$, mesenchymal $(19 \%)$, and proliferative $(27 \%)$. Patients with mesenchymal and proliferative tumors had a worse prognosis compared to the differentiated and immunoreactive subgroups (18). Data from randomized trials are still pending, and researchers are looking for biological factors to identify women who could most benefit from the addition of bevacizumab therapy.

Nevertheless, limitations of paclitaxel-platinum-based chemotherapy with bevacizumab treatment strategies lie in the fact that median PFS after first-line therapy is a maximum of 18 months and progressive disease develops in more than $70 \%$ of patients within three years. Therefore, 
there is a significant need for better frontline treatment to avoid or delay relapse and improve women's outcomes with ovarian cancer. The ideal scenario is to develop a treatment that would demonstrate a significant benefit in PFS during first-line treatment. The difference between treatments would continue to be upheld during subsequent treatments, leading ultimately to a difference in OS, which is rarely seen, partly because of the extended post-progression survival in ovarian cancer, with multiple subsequent treatments and, in some situations, crossover to the experimental therapy (19). As in the trial of maintenance olaparib therapy in platinum-sensitive recurrent ovarian cancer (Study19), there were considerable differences in PFS but much smaller OS (20). An exploratory analysis removing patients where crossover occurred showed a significant difference in OS with maintenance olaparib (21). Additionally, because of an extended post-progression survival, OS endpoint often becomes available several years after recruitment to the trial was completed. As there is academic and regulatory pressure to analyze results early, PFS has become a primary endpoint for many first-line trials (19).

Recently, a significant breakthrough happened with the introduction of Poly (ADP-ribose) polymerase (PARP) inhibitors. They inhibit and trap PARP on deoxyribonucleic acid (DNA) at single-strand break sites. This prevents the repair of these breaks and generates double-strand breaks that cannot be repaired accurately in tumors with homologous-recombination deficiency (HRD), causing tumor cell death (synthetic lethality). Approximately $20-30 \%$ of ovarian carcinomas have germline or somatic BRCA1 or BRCA2 mutations. HRD is not limited to tumors with BRCA mutations and is present in approximately $50 \%$ of highgrade serous ovarian tumors. These alterations increase tumor susceptibility to agents, including platinum and PARP inhibitors (22).

The efficacy of PARP inhibitors (olaparib, niraparib, rucaparib) has been confirmed in several clinical studies phase III (SOLO2, NOVA, and ARIEL3) in patients with platinum-sensitive relapse $(23,24,25)$. The next step was to examine their efficacy and tolerability in the first-line treatment after responding to platinum-paclitaxelbased chemotherapy.

The SOLO1 trial evaluated the efficacy of maintenance therapy with PARP inhibitor olapar- $\mathrm{ib}$ in patients with newly diagnosed advanced ovarian cancers whose tumors had germline or somatic BRCA1/2 mutations. This study enrolled 391 patients with stage III $(85 \%)$ and stage IV $(15 \%)$. The majority of them had no residual disease after cytoreductive surgery, and complete radiological response to chemotherapy was confirmed in $85 \%$ of patients. They were randomized to receive olaparib $300 \mathrm{mg}$ twice daily versus placebo until radiological disease progression, unacceptable toxicity or for up to 2 years for a complete response. The primary endpoint was PFS. Results were presented at the ESMO 2018 meeting. PARP inhibitor olaparib provided a substantial progression-free survival benefit as maintenance monotherapy in a select group of patients with newly diagnosed advanced ovarian cancer whose tumors had a BRCA mutation and had a complete or partial clinical response after platinum-based chemotherapy. The median PFS was not reached in the olaparib arm vs. 13,8 months in the placebo arm. After three years, $60 \%$ of patients in the olaparib arm were without disease progression vs. $27 \%$ in the placebo arm (HR 0.30; $P<0.001)(26)$. After two years, at the ESMO Virtual Congress 2020 , investigators presented data from the SOLO1 trial after the most extensive follow-up for any PARP inhibitor in the first-line setting. Almost half of the patients were progression-free vs. $20 \%$ in the placebo arm (HR 0.33), and more than half of women in complete response at baseline who received maintenance olaparib for two years remained free from relapse five years later (HR 0.37) (27). The SOLO1 study results are consistent with Study19 and SOLO2 trials investigating olaparib in recurrent ovarian cancer $(20,23,28)$.

At the ESMO 2019 meeting, three new clinical trials phase III with three different PARP inhibitors and a different way of incorporating in first-line treatment showed substantial benefit when used in patients with newly diagnosed ovarian cancer. Niraparib, olaparib with Bevacizumab, and veliparib clinically and statistically significant prolonged PFS after first-line platinum-based chemotherapy.

PRIMA trial evaluated efficacy and safety of niraparib maintenance therapy after response to platinum-based chemotherapy in patients with newly diagnosed advanced ovarian cancer at high risk for relapse (stage III with visible residual disease after primary debulking or inoperable stage III, stage IV, and those who had received neoadju- 
vant chemotherapy). Niraparib significantly improved PFS when compared with placebo, regardless of the presence or absence of HRD. In the overall population, the median PFS was 13,8 vs. 8,2 months (HR 0.62, $P<0.001$ ). The benefit from niraparib was even more significant in the subgroup of $51 \%$ of patients with HRD (mPFS 21,9 vs. 10,4 months, HR 0.43 ). In patients with HRD proficient tumors, niraparib monotherapy provides clinically significant benefits too. The most common adverse events of grade 3 or higher were anemia, thrombocytopenia, and neutropenia (29). The PRIMA study results are consistent with NOVA and QUADRA trials investigating niraparib in recurrent ovarian cancer $(30,31)$.

According to preclinical data, hypoxia-induced by an antiangiogenic treatment can induce, or at least increase HRD, which means that Bevacizumab may increase olaparib activity in patients HRD-positive tumors and, in particular, patients with HRD-positive tumors without a BRCA mutation. The addition of an antiangiogenic agent to a PARP inhibitor in phase 2 studies involving patients with relapsed platinum-sensitive ovarian cancer resulted in longer PFS than the use of a PARP inhibitor alone $(32,33)$. In the phase III PAOLA-1 trial, investigators evaluated maintenance therapy with olaparib compared with placebo in patients with newly diagnosed advanced ovarian cancer receiving chemotherapy plus Bevacizumab followed by Bevacizumab. The PAOLA-1 population was representative of the majority of patients with advanced ovarian cancer because the patient selection was not restricted based on the surgical outcome or BRCA mutation status. Maintenance therapy with olaparib and Bevacizumab vs. Bevacizumab significantly improved mPFS (22,1 vs. 16,6 months; HR 0.59 , $P<0.0001)$. The magnitude benefit was most remarkable for those whose tumors had BRCA mutations (mPFS 37,1 vs. 21,7 months; HR 0.31). Patients with HRD negative tumors did not benefit in PFS when they received olaparib with Bevacizumab compared to Bevacizumab only. Olaparib did not impact bevacizumab tolerability and quality of life (34). Following the SOLO1 trial and PAOLA-1 study results, it is difficult to define the real impact of bevacizumab addition in the frontline maintenance strategy. For now, it looks like monotherapy is the preferred option due to less toxicity (patient and financial) and similar efficacy.
Another approach with concomitant ordination of PARP inhibitor and chemotherapy was evaluated in the VELIA trial. This trial evaluated the safety and efficacy of veliparib concurrent with chemotherapy. It continued as maintenance in previously untreated patients with advanced highgrade serous ovarian carcinoma regardless of biomarker, surgery choice, or paclitaxel regimen. In the intention-to-treat population, $\mathrm{mPFS}$ was 23,5 vs 17,3 months (HR $0.68, P<0.001$ ), in the BRCAm cohort 34,7 vs 22 months, (HR 0.44, $P<0.001$ ) and in HRD cohort 31,9 vs 20,5 months (HR 0.57, $P<0.001$ ). Veliparib given concurrently with chemotherapy only did not benefit in PFS. The trial design did not include an arm with veliparib maintenance only and therefore did not prospectively address the relative contribution of maintenance therapy with veliparib. This PARP inhibitor led to a higher incidence of anemia and thrombocytopenia, combined with chemotherapy (35).

The use of PARP inhibitors (olaparib only, olaparib concurrent with Bevacizumab, niraparib only, veliparib concurrent with chemotherapy followed by maintenance) as first-line maintenance therapy for advanced ovarian cancer improves PFS, according to four phase III studies (36). The effectiveness of PARP inhibitors has been evaluated in three different biological subtypes of ovarian cancer. Patients with BRCA mutated tumors obtain the most significant benefit in PFS. The HRD-positive BRCA wild type can be considered a new clinical population that showed a similar benefit compared to the BRCA-mutated subgroup from the addition of a PARP inhibitor.

Conversely, the HRD-negative population achieved a modest survival advantage from niraparib monotherapy after a response to first-line chemotherapy. Since no comparison with the Bevacizumab was performed in the PRIMA trial, for HRD negative patients, niraparib, or bevacizumab maintenance could be both valid options (37). PARP inhibitors have an acceptable toxicity profile and ensure a good quality of life $(36,37)$. However, several ongoing studies of new combination strategies (NCT03737643 - phase III trial with platinum-based chemotherapy, durvalumab, bevacizumab and olaparib , NCT03602859 - phase III trial with platinum-based chemotherapy, dostarlimab and niraparib) could clearly define the role of PARP inhibitors as maintenance therapy in the first-line setting of ovarian cancers. The magni- 
Lib Oncol. 2020;48(2-3):77-84

Table 3.

PARP inhibitors in first-line treatment

\begin{tabular}{|c|c|c|c|c|c|c|}
\hline Study & Patients & Arms (S vs C) & $\begin{array}{l}\text { PFS, overall } \\
\text { population, months }\end{array}$ & $\begin{array}{l}\text { PFS, BRCAm } \\
\text { population, months }\end{array}$ & $\begin{array}{l}\text { PFS, HRD+ } \\
\text { population, months }\end{array}$ & $\begin{array}{l}\text { PFS, HRD- } \\
\text { population, months }\end{array}$ \\
\hline SOLO-126,27 & $\begin{array}{l}\text { BRCAm } \\
\text { NADOC }\end{array}$ & \begin{tabular}{|l} 
Olaparib \\
maintenance \\
vs placebo \\
\end{tabular} & - & $\begin{array}{l}\text { NR }(S) \text { vs } 13.8(C) ; \\
\text { HR } 0.30 ; \\
P<0.001\end{array}$ & - & - \\
\hline PRIMA $^{29}$ & All NADOC & $\begin{array}{l}\text { Niraparib } \\
\text { maintenance } \\
\text { vs placebo } \\
\end{array}$ & $\begin{array}{l}13.8(\mathrm{~S}) \text { vs } 8.2(\mathrm{C}) \\
\text { HR } 0.62 \\
P<0.001\end{array}$ & $\begin{array}{l}22(\mathrm{~S}) \text { vs } 10(\mathrm{C}) \\
\text { HR } 0.40 \\
P<0.001\end{array}$ & $\begin{array}{l}21.9(\mathrm{~S}) \text { vs } 10.4(\mathrm{C}) \\
\text { HR } 0.43 \\
P<0.001\end{array}$ & $\begin{array}{l}8.1(\mathrm{~S}) \text { vs } 5.4(\mathrm{C}) \\
\text { HR } 0.68 \\
P=0.02\end{array}$ \\
\hline PAOLA $^{34}$ & All NODOC & $\begin{array}{l}\text { Olaparib } \\
\text { + bevacizumab } \\
\text { maintenance } \\
\text { vs bevacizumab } \\
\text { maintenance } \\
\text { + placebo }\end{array}$ & $\begin{array}{l}22.1(\mathrm{~S}) \text { vs } 16.6(\mathrm{C}) \\
\text { HR } 0.59 \\
P<0.001\end{array}$ & $\begin{array}{l}37.2(\mathrm{~S}) \text { vs } 21.7(\mathrm{C}) \\
\text { HR } 0.31 \\
P<0.001\end{array}$ & $\begin{array}{l}37.2(\mathrm{~S}) \text { vs } 17.7(\mathrm{C}) \\
\text { HR } 0.33 \\
P<0.001\end{array}$ & $\begin{array}{l}16.9(\mathrm{~S}) \text { vs } 16(\mathrm{C}) \\
\text { HR } 1.00\end{array}$ \\
\hline VELIA $^{35}$ & All NODOC & $\begin{array}{l}\text { Veliparib + CHT } \\
\text { maintenance } \\
\text { vs veliparib + CHT } \\
\text { placebo }\end{array}$ & $\begin{array}{l}23.5(\mathrm{~S}) \text { vs } 17.3(\mathrm{C}) \\
\text { HR } 0.68 \\
P<0.001\end{array}$ & $\begin{array}{l}34.7(\mathrm{~S}) \text { vs } 22(\mathrm{C}) \\
\text { HR } 0.44 \\
P<0.001\end{array}$ & $\begin{array}{l}31.9(\mathrm{~S}) \text { vs } 20.5(\mathrm{C}) \\
\text { HR } 0.57 \\
P<0.001\end{array}$ & $\begin{array}{l}15(\mathrm{~S}) \text { vs } 11(\mathrm{C}) \\
\text { HR } 0.81\end{array}$ \\
\hline
\end{tabular}

*NADOC, newly diagnosed advanced ovarian cancer; S, study arm; C, control arm; CHT, chemotherapy; HR, hazard ratio; PFS, progression free survival

tude of benefit varies widely among subgroups, highlighting the need to identify specific biological subtypes in clinical practice. In this regard, it is necessary to introduce HRD testing, which is currently expensive, time-consuming, and not reproducible in standard laboratories. Finally, validated biomarkers to quantify the HRD status in each patient are warranted to identify the subgroup of patients who derived more benefit from PARP inhibitors (38) (Table 3).

In conclusion, the first-line treatment for advanced ovarian cancer can be summarized through the three steps. The first step involves selecting patients based on the extend of the disease to initially operable with presumed $\mathrm{R} 0$ resection and inoperable disease, followed by neoadjuvant treatment. The second step implies systemic treatment with platinum-based chemotherapy strengthened by bevacizumab and/or PARP inhibitors, depending on the risk of recurrence and molecular/genetic changes. The third step represents new treatment options, i.e., new drugs or combinations of existing drugs. All three steps are based on the personalized treatment that should improve ovarian cancer patients' outcomes.

\section{REFERENCES}

1. Colombo N, Sessa C, Du Bois A, et al. ESMO-ESGO consencus conference recommendation on ovarian cancer: pathology and molecular biology, early and advanced stages, borderline tumours and reccurent disease. Ann Oncol. 2019;30:672-705.

2. Katsumata N, Yasuda M, Isonishi S, et al. Long-term results of dose-dense paclitaxel and carboplatin versus conventional paclitaxel and carboplatin for treatment of advanced epithelial ovarian, fallopian tube, or primary peritoneal cancer (JGOG 3016): a randomised, controlled, open-label trial. Lancet 2013;14 (10):1020-1026.

3. Armstrong D, Bundy B, Wenzel L, et al. Phase III randomized trial of intravenous cisplatin and paclitaxel versus an intensive regimen of intravenous paclitaxel, intraperitoneal cisplatin and intraperitoneal paclitaxel in stage III ovarian cancer: a Gynecologic Oncology Group study. N Engl J Med. 2006;354:34-43.

4. Vergote I, Tropé CG, Amant F, et al. Neoadjuvant chemotherapy or primary surgery in stage IIIC or IV ovarian cancer. N Engl J Med. 2010;363(10):943-53.

5. Kehoe S, Hook J, Nankivell M, et al. Primary chemotherapy versus primary surgery for newly diagnosed advanced ovarian cancer (CHORUS): an open-label, randomised, controlled, non-inferiority trial. Lancet. 2015;386(9990):249-257.

6. Marchetti C, Muzii L, Romito A, et al. First-line treatment of women with advanced ovarian cancer: focus on bevacizumab. OncoTarget and Therapy. 2019:12, 1095-1103.

7. Hall M, Gourley C, McNeish I, et al. Targeted antivascular therapies for ovarian cancer:current evidence. Br J Cancer. 2013;108(2):250-258.

8. Burger RA, Brady MF, Bookman MA, i sur. Incorporation of bevacizumab in the primary treatment of ovarian cancer. N Engl J Med. 2011;365(26):2473-2483.

9. Robert AB, Danielle E, Kirshnansz ST. Final overall survival (OS) analysis o fan international randomized 
trial evaluating bevacizumab (BEV) in the primary treatment od advanced ovarian cancer; a NRG oncology/Gynecologic Oncology Group (GOG) study. J Clin Oncol. 2018;36(15 Suppl):5517.

10. Perren TJ, Swart AM, Pfisterer J, et al. A phase 3 trial of bevacizumab in ovarian cancer. N Engl J Med. 2011; 365 (26):2484-2496.

11. Oza AM, Cook AD, Pfisterer J, et al. Standard chemotherapy with or without bevacizumab for women with newly diagnosed ovarian cancer (ICON7): overall survival results of a phase 3 randomised trial. Lancet Oncol. 2015;16(8):928-936.

12. Pignata S, Scambia G, Katsaros D, et al. Gynecologic Cancer InterGroup (GCIG) Investigators. Carboplatin plus paclitaxel once a week versus every 3 weeks in patients with advanced ovarian cancer (MITO-7): a randomized, multicentre, open-label, phase 3 trial. Lancet Oncol. 2014;15(4):396-405.

13. Clamp AR, et al. ICON8: Overall survival results in GCIG phase III randomized controlled trial of weekly dose-dense chemotherapy in first line epithelial ovarian, fallopian tube or primary peritoneal carcinoma treatment. ESMO Virtual Congress 2020, Abstract $805 \mathrm{O}$

14. Oza AM, Selle F, Davidenko I, et al. Efficacy and safety of bevacizumab-containing therapy in newly diagnosed ovarian cancer: ROSiA single-arm phase 3B study. Int J Gynecol Cancer. 2017;27(1):50-58.

15. A prospective randomised phase III trial to evaluate optimal treatment duration of first-line bevacizumab in combination with carboplatin and paclitaxel in patients with primary epithelial ovarian, fallopian tube or peritoneal cancer. AGO-OVAR17. NCT number: NCT01462890, ClinicalTrials.gov. https://clinicaltrials. gov/ct2/show/NCT01462890 (accessed on 11/02/2020)

16. Rouzier R, Gouy S, Selle F, et al. Efficacy and safety of bevacizumab-containing neoadjuvant therapy followed by interval debulking surgery in advanced ovarian cancer: results from the ANTHALYA trial. Eur J Cancer. 2017;70:133-142.

17. Daniele G, Lorusso D, Scambia G, et al. Feasibility and outcome of interval debulking surgery (IDS) after carboplatin-paclitaxel-bevacizumab (CPB): a subgroup analysis of the MITO-16A-MaNGO OV2A phase 4 trial. Gynecol Oncol. 2017;144(2):256-259.

18. Kommoss S, Winterhoff B, Oberg AL, et al. Bevacizumab may differentially improve ovarian cancer outcome in patients with proliferative and mesenchymal molecular subtypes. Clin Cancer Res. 2017; 23(14): 3794-3801.

19. Ledermann JA. First-line treatment of ovarian cancer: questions and controversies to address. Ther Adv Med Oncol. 2018 (10):1-8.

20. Ledermann J, Harter P, Gourley C et al. Olaparib maintenance therapy in patients with platinum-sensitive relapsed serous ovarian cancer: a preplanned retrospective analysis of outcomes by BRCA status in a randomised phase 2 trial. Lancet Oncol. 2014;15(8): 852-861.

21. Matulonis UA, Harter P, Gourley C, et al. Olaparib maintenance therapy in patients with platinum-sensitive, relapsed serous ovarian cancer and a BRCA mutation: overall survival adjusted for postprogression poly(adenosine diphosphate ribose) polymerase inhibitor therapy. Cancer 2016;122:1844-1852.

22. Faraoni I, Graziani G. Role of BRCA mutations in cancer treatment with poly(ADP-ribose)polymerase (PARP) inhibitors. Cancers (Basel). 2018;10:487.

23. Pujade-Lauraine E, Ledermann JA, Selle F, et al. Olaparib tablets as maintenance therapy in patients with platinum-sensitive, relapsed ovarian cancer and a BRCA1/2mutation (SOLO2/ENGOT-Ov21): a doubleblind, randomised, placebo-controlled, phase 3 trial. Lancet Oncol. 2017;18(9):1274-1284.

24. Mirza MR, Monk BJ, Herrstedt J, i sur. Niraparib maintenance therapy in platinum-sensitive, recurrent ovarian cancer. N Engl J Med. 2016;375(22):2154-2164.

25. Ledermann JA, Oza AM, Larusso D, et al. Rucaparib for patients with platinum-sensitive, recurrent ovarian carcinoma (ARIEL-3): post-progression outcomes and updated safety results from randomised placeocontrolled phase 3 trial. Lancet Oncol. 2020;21(5): 710-722.

26. Moore K, Colombo N, Scambia G, et al. Maintenance olaparib in patients with newly diagnosed advanced ovarian cancer. N Engl J Med. 2018;379:2495-2505.

27. Banerjee S, Moore KN, Colombo N, et al. Maintenance olaparib for patients (pts) with newly diagnosed, advanced ovarian cancer (OC) and a BRCA mutation (BRCAm); 5-year (y) follow-up (f/u) from SOLO1. ESMO Virtual Congress 2020, Abstract 811M0.

28. Poveda A, Floquet A, Ledermann JA, et al. Final overall survival (OS) results from SOLO2/ENGOT-Ov21: A phase III tral assessing maintance olaparib in patients (pts) with platinum-sensitive, relapsed ovarian cancer and a BRCA mutation. ASCO Virtual Congress 2020, Abstract 6002.

29. Gonzalez-Martin A, Pothuri B, Vergote I, et al. Niraparib in patients with newly diagnosed advanced ovarian cancer. N Engl J Med. 2019;381:2391-2402.

30. Mirza MR, Monk BJ, Herrstedt J, et al. Niraparib maintenance therapy in platinum-sensitive, recurrent ovarian cancer. N Engl J Med. 2016;375:2154-2164.

31. Moore KN, Secord AA, Geller MA, et al. Niraparib monotherapy for late-line treatment of ovarian cancer (QUADRA): a multicenter, open-label, single-arm, phase 2 trial. Lancet Oncol. 2019;20:636-648.

32. Mirza MR, Avall-Lundqvist E, Birrer MJ, et al. Combination of niraparib and bevacizumab versus niraparib alone as treatment of recurrent platinum-sensitive ovarian cancer: a randomized controlled chemotherapy-free study - NSGOAVANOVA2/ ENGOT-OV24. J Clin Oncol. 2019;37: Suppl:5505.abstract. 
33. Liu JF, Barry WT, Birrer M, et al. Overall survival and updated progression-free survival outcomes in a randomized phase II study of combination cediranib and olaparib versus olaparib in relapsed platinum-sensitive ovarian cancer. Ann Oncol. 2019;30: 551-557.

34. Ray-Coquard I, Pautier P, Pignata S, et al. Olaparib plus bevacizumab as first-line maintenance in ovarian cancer. N Engl J Med. 2019;381:2416-2428.

35. Coleman RL, Fleming GF, Brady MF, et al. Veliparib with first-line chemotherapy and as maintenance therapy in ovarian cancer. N Engl J Med. 2019;381: 2403-2415.

36. Franzese E, Diana A, Centonze S, et al. PARP inhibitors in first-line therapy of ovarian cancer: Are there any doubts? Front Oncol. 2020;10:782

37. Caruso D, Papa A, Tomao S, et al. Niraparib in ovarian cancer: results to date and clinical potential. Ther Adv Med Oncol. 2017;9:579-588.

38. Banerjee SN, Lord CJ. First-line PARP inhibition in ovarian cancer-standard of care for all? Nat Rev Clin Oncol. 2020;17:136-137.

Sažetak

PRVOLINIJSKO LIJEČENJE UZNAPREDOVALOG RAKA JAJNIKA: NOVOSTI

\section{B. Petrić Miše}

Rak jajnika je peti najčešći uzrok smrti među zloćudnim bolestima kod žena u Europi. Standardni način liječenja je primarna citoredukcija praćena kemoterapijom temeljenom na platini i taksanima. Kod bolesnica s uznapredovalom bolesti jedna od opcija liječenja je neoadjuvantna kemoterapija s intervalnom citoredukcijom. Unatoč napretku u liječenju, gotovo $70 \%$ bolesnica razvije povrat bolesti. Postoji značajna potreba za poboljšanjem prvolinijskog liječenja s ciljem izbjegavanja ili odgađanja povrata bolesti i poboljšanja ishoda liječenja bolesnica s rakom jajnika. Najvažnija promjena uključuje izmjene u načinu primjene lijekova i dodavanje novih lijekova prvolinijskoj kemoterapiji. Bevacizumab je odobren u prvolinijskom liječenju u kombinaciji s karboplatinom i paklitakselom zbog poboljšanja preživljenja do napredovanja bolesti (PFS) kod bolesnica s povećanim rizikom od recidiva. Terapija održavanja PARP inhibitorima, nakon odgovora na prvolinijsku kemoterapiju, produljuje PFS kod bolesnica s poremećajem u sustavu popravka dvostrukih lomova deoksiribonukleinske kiseline homolognom rekombinacijom. Najveću korist imaju bolesnice s BRCA mutacijama.

KLJUČNE LIJEČI: karcinom jajnika, kemoterapija, bevacizumab, PARP inhibitori 